\title{
Hyperlipidaemia in Asthmatic Patients Receiving Long-term Steroid Therapy
}

\author{
A. H. EL-SHABOURY, T. M. HAYES
}

British Medical fournal, 1973, 2, 85-86

\begin{abstract}
Summary
Plasma lipids were measured in $\mathbf{1 0 0}$ female asthmatic patients receiving long-term steroid therapy. A significant increase in the incidence of endogenous hypertriglyceridaemia but not of hypercholesterolaemia was found. The hypertriglyceridaemia was not due to obesity or diabetes. Neither the dose of steroid, duration of therapy, nor the addition of corticotrophin gel or depot tetracosactrin influenced the prevalence of hypertriglyceridaemia.
\end{abstract}

\section{Introduction}

Though it is recognized that treatment with steroids alters plasma lipids, the prevalence of hyperlipoproteinaemia in patients receiving long-term steroid therapy is not known. Raised plasma cholesterol (Adlersberg et al., 1950), triglycerides, and phospholipids (Bagdade et al., 1970) were found in patients with collagen diseases treated with large doses of corticotrophin or adrenal steroids for periods of up to six months. However, treatment with steroids for several hours or days is known to cause a fall in various lipid fractions (Oliver and Boyd, 1956; Skanse et al., 1959; Moses et al., 1962; Nayak et al., 1962; Kyner et al., 1972) and this fall may be more pronounced after corticotrophin than adrenal steroids (Danowski et al., 1962; Friedman et al., 1967).

Our interest arose when four of 20 steroid-treated asthmatic patients who were also given depot tetracosactrin regularly for two to two and a half years died unexpectedly with cardiac infarction within a few months of each other. We decided, therefore, to investigate a group of asthmatic patients whose steroid therapy has been carefully controlled over the past five years by one of us (A.H.EL-S).

\section{Materials and Methods}

The study was of 100 female asthmatic patients (aged 2975 years) on continuous treatment with prednisone $5-15 \mathrm{mg} /$ day for periods ranging from four to 13 years. Of these 100 patients 53 also received corticotrophin gel injections (40 to 120 units/week) for three to five years, 12 received depot tetracosactrin $(0.5$ to $3 \mathrm{mg} /$ week) for two to four years, and the remaining 35 patients continued on their maintenance dose of prednisone alone. Seventeen of the 65 patients who were receiving either corticotrophin gel or depot tetracosactrin had discontinued their injections for two to 45 months before the study. Fifty normal female subjects taken from a population survey by the M.R.C. Epidemiology Unit (S. Wales) served as controls.

\footnotetext{
Department of Medicine, Welsh National School of Medicine, and University Hospital of Wales, Cardiff

A. H. EL-SHABOURY, M.D., D.C.H., Senior Registrar

T. M. HAYES, M.B., M.R.C.P., Senior Lecturer
}

Venous blood was taken after an overnight fast, plasma was separated immediately and stored at $4^{\circ} \mathrm{C}$ for lipoprotein electrophoresis and at $-20^{\circ} \mathrm{C}$ before analysis of cholesterol and triglycerides. These estimations were carried out within three days of venepuncture. Plasma cholesterol was measured by the Liebermann-Burchard reaction (Ferro and Ham, 1960) and triglycerides by a modification of the method of Van Handel and Zilverschmidt (1957) using isopropanol extraction (Kessler and Lederer, 1965) and mannitol as a standard (Kanter, 1967). In our hands the coefficient of variation for replicate assays of triglycerides in a quality control sera was $2.96 \%$, and for estimations carried out on different days was $3 \cdot 10 \%$. Lipoprotein electrophoresis was carried out on cellulose acetate by the method of Postma and Stroes (1968) and the abnormalities were classified according to the system of Fredrickson et al. (1967). The upper limit of normal for plasma cholesterol was taken as $280 \mathrm{mg} / 100 \mathrm{ml}$ and for plasma triglyceride as $2.0 \mathrm{mmol} / \mathrm{l}$. Ponderal indices were calculated by the method of Khosla and Lowe (1967).

\section{Results}

There was no significant difference between the mean age and ponderal index in the control subjects and steroid-treated asthmatic patients, as shown in table I. The prevalence of hyperlipoproteinaemia is shown in table II. It can be seen that type IV hyperlipoproteinaemia (endogenous hypertriglyceridaemia) was significantly more prevalent in the steroid-treated group but no difference was noted in the frequency of type II hyperlipoproteinaemia (hypercholesterolaemia). The mean value for plasma cholesterol was similar in controls and patients but the mean value for triglycerides was significantly higher in the patients (table III).

TABLE I-Mean Age and Ponderal Index in Control Subjects and Steroidtreated Patients

\begin{tabular}{|c|c|c|c|}
\hline & & Control Subjects & Patients on Steroids \\
\hline $\begin{array}{l}\begin{array}{l}\text { No. of patients } \\
\text { Age }( \pm \text { S.D. }\end{array} \\
\text { Ponderal index }\end{array}\left(\begin{array}{l} \pm \text { S.D. }) \\
\text { Pon }\end{array}\right.$ & $\begin{array}{l}\cdots \\
\because\end{array}$ & $\begin{array}{c}50 \\
53.96 \text { years }( \pm 8 \cdot 0) \\
3.51( \pm 0.97)\end{array}$ & $\begin{array}{c}100 \\
54.04 \text { years }( \pm 9.4) \\
3.67( \pm 0.5 \overline{8})\end{array}$ \\
\hline
\end{tabular}

TABLE II-Hyperlipoproteinaemia in 50 Control Subjects and 100 Steroidtreated Patients

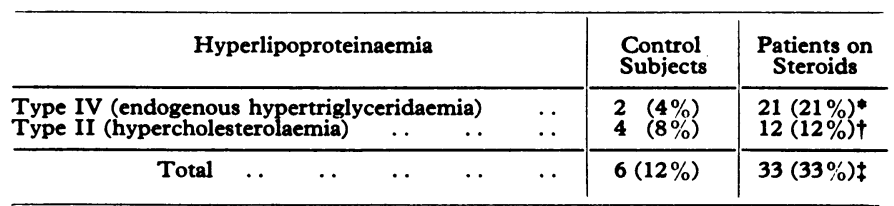

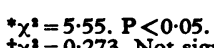

$+x^{2}=0.273$. Not significant.
$\pm x^{2}=5.63 . P<0.05$.

Analysis of the results showed that there was no significant difference in the prevalence of lipid abnormalities between patients receiving the three regimens of steroids (prednisone alone, prednisone plus corticotrophin gel, and prednisone plus 
TABLE III-Mean Plasma Triglycerides and Cholesterol in Control Subjects and Steroid-treated Patients

\begin{tabular}{|c|c|c|}
\hline & $\begin{array}{l}\text { Control } \\
\text { Subjects }\end{array}$ & $\begin{array}{l}\text { Patients on } \\
\text { Steroids }\end{array}$ \\
\hline $\begin{array}{l}\text { Triglycerides (mmol/1.) Mean } \pm \text { S.D. }) \\
\text { Cholesterol }(\mathrm{mg} / 100 \mathrm{ml})(\text { Mean } \pm \text { S.D. })\end{array}$ & $\begin{array}{r}1 \cdot 29 \pm 0.31 \\
250 \cdot 90 \pm 52 \cdot 90\end{array}$ & $\begin{array}{r}1 \cdot 76^{*} \pm+0 \cdot 61 \\
244 \cdot 50+ \pm 46 \cdot 30\end{array}$ \\
\hline
\end{tabular}

$t=6 \cdot 22, \mathrm{P}<0.05$

tNot significant.

depot tetracosactrin) (table IV). Also, the prevalence of abnormal plasma lipids did not differ in those patients who had discontinued their injections or those who were still receiving this therapy at the time of study. Neither the duration of prednisone treatment nor the average daily dose was significantly different in those patients with normal or abormal lipids (table V).

TABLE IV-Plasma Lipids in Patients Receiving Various Regimens of Steroids

\begin{tabular}{|c|c|c|c|c|}
\hline \multirow{2}{*}{ Type of Treatment } & \multirow{2}{*}{$\begin{array}{c}\text { Total } \\
\text { No. of } \\
\text { Patients }\end{array}$} & \multicolumn{3}{|c|}{ Plasma Lipids } \\
\hline & & Normal & Type II & Type IV \\
\hline $\begin{array}{l}\text { Prednisone alone } \\
\text { Prednisone and corticotrophin gel } \\
\text { Prednisone and depot tetracosactrin }\end{array}$ & $\begin{array}{l}35 \\
53 \\
12\end{array}$ & $\begin{array}{r}25 \\
33 \\
9\end{array}$ & $\begin{array}{l}5 \\
7 \\
1\end{array}$ & $\begin{array}{r}5 \\
13 \\
2\end{array}$ \\
\hline
\end{tabular}

TABLE V-Mean Duration of Steroids and Average Daily Dose in Patients with Normal and Abnormal Plasma Lipids

\begin{tabular}{|c|c|c|c|}
\hline & $\begin{array}{l}\text { Patients with } \\
\text { Normal Lipids } \\
\quad(\mathbf{n}=\mathbf{6 7})\end{array}$ & $\begin{array}{l}\text { Patients with } \\
\text { Abnormal Lipids } \\
(n=33)\end{array}$ & $t$ Test \\
\hline $\begin{array}{l}\text { Mean duration of steroids (in } \\
\text { months) }( \pm \text { S.D. }) \\
\text { Average prednisone dose } \\
\text { (mg/day) }( \pm \text { S.D. })\end{array}$ & $\begin{array}{l}\bar{x}=114.5 \pm 28.91 \\
\bar{x}=8.46 \pm 3.165\end{array}$ & $\begin{array}{l}\bar{x}=104.48 \pm 37.75 \\
\vec{x}=8.79 \pm 3.02\end{array}$ & $\begin{array}{l}1.35^{*} \\
0.513^{*}\end{array}$ \\
\hline
\end{tabular}

*Not significant.

Only 11 of the 100 asthmatic patients were noted to have glycosuria at some time during five years of observation. Of these 11 patients the glycosuria was noted on one occasion only in nine, and two of these had type II and another had type IV hyperlipoproteinaemia. The remaining two patients had glycosuria recorded on more than one occasion; one had normal lipids and the other had type II hyperlipoproteinaemia.

\section{Discussion}

The prevalence of plasma lipid abnormalities in asthmatic patients receiving long-term steroid therapy has not been reported previously. We have found endogenous hypertriglyceridaemia in 21 of 100 patients compared with only $4 \%$ in control subjects. The incidence of hypercholesterolaemia, however, was similar in both patients and controls. Adlersberg et al. (1950) found that plasma cholesterol rose during treatment with steroids for several months and Skanse et al. (1959) noted an initial fall in plasma cholesterol followed by a rise within a few days of starting steroids. We have not taken repeated samples for plasma lipid analysis but the mean for cholesterol values was similar in our patients and controls and steroid therapy was given for a much longer period (average of nine years).

The reason for increased hypertriglyceridaemia found in this study is not clear. We have not excluded the possibility that it may be due to asthma, since we were unable to study a control group of asthmatic patients who had not received steroids or other drugs which may influence lipid metabolism. It is not due to obesity or diabetes; the ponderal index was not different in patients and controls, and the few patients who had occasional glycosuria did not have an increased incidence of hypertriglyceridaemia. Similarly, the dose of prednisone, duration of treatment, or the addition of corticotrophin gel or depot tetracosactrin was not related to the prevalence of hypertriglyceridaemia. Bagdade et al. (1970) reported a noticeable increase in carbohydrate intolerance, hypercholesterolaemia, and hypertriglyceridaemia in two patients with collagen disease treated with 80 to $120 \mathrm{mg}$ of prednisone a day. These changes, however, reverted to normal on reduction of steroid dose and unlike these two cases our patients' maintenance dose of prednisone did not exceed $15 \mathrm{mg} /$ day. The endogenous hypertriglyceridaemia noted in the present study may be due to increased hepatic synthesis of very low density lipoproteins. This could result from increased supply of free fatty acids resulting from stimulation of mobilizing lipase either by steroids or the effect of sympathomimetic amines used by patients with asthma. There is some experimental evidence to support this hypothesis (Nayak et al., 1962; Mahler and Stafford, 1963; Scow and Chernick, 1970) and further investigation is indicated.

We wish to thank Dr. D. A. Williams for allowing the study of patients under his care, Miss B. M. John for the lipid analysis, Dr. D. Bainton for providing the controls, and Professor R. Mahler for criticism.

\section{References}

Adlersberg, D., Schaeffer, L., and Drachman, S. R. (1950). Fournal of the American Medical Association, 144, 909.

Bagdade, J. D., Porte, D., and Bierman, E. L., (1970) Archives of Internal Medicine, 125, 129.

Danowski, T. S., Heineman, A. C., jun., and Moses, C. (1962). Metabolism,

Ferro, P. V., and Ham, A. B. (1960). American fournal of Clinical Pathology,

Fredrickson, D. S., Levy, R. I., and Lees, R. S. (1967). New England fournal of Medicine, 276, 34

Friedman, M., Rosenman, R. H., Byers, S. O., and Eppstein, S. (1967). Fournal of Clinical Endocrinology and Metabolism, 27, 775.

Kanter, S. L. (1967). Clinica Chimica Acta, 16, 177.

Kessler, G., and Lederer, H. (1965). In Automation in Analytical Chemistry ed. L. T. Skegg, jun., p. 341. New York, Mediad.

Khosla, T., and Lowe, C. R. (1967). British fournal of Preventive and Socia Medicine, 21, 122

Kyner, J. L., Levy, R. I., Soeldner, J. S., Gleason, R. E., and Fredrickson, D. S. (1972). Metabolism, 21, 329.

Mahler, R. F., and Stafford, W. L. (1963). In Control of Lipid Metabolism, ed. J. K. Grant, p. 155. London, Academic Press.

Moses, C., Jablonski, J. R., Sunder, J. H., Greenman, J. H., and Danowski, T. S., Jablonsk, J. R., Sunder, J.

Nayak, R. V., Feldman, E. B., and Carter, A. C. (1962). Proceedings of The Society for Experimental Biology and Medicine, 111, 682.

Society for Experimental Biology and Medicine, 111,
Oliver, M. F., and Boyd, G. S. (1956). Lancet, 2, 1273.

Oliver, M. F., and Boyd, G. S. (1956). Lancet, 2, 1273.

Scow, R. O., and Chernick, S. S. (1970). In Comprehensive Biochemistry, ed. M. Florkin and E. H. Stotz, vol. 18, p. 19. Amsterdam, Elsevier.

Skanse, B., Von Stundnitz, W., and Skoog, N. (1959). Acta Endocrinologica (Kфbenhaven), 31, 442.

Van Handel, E., and Zilverschmidt, D. B. (1957). Fournal of Laboratory and Clinical Medicine, 50, 152. 